\title{
Evaluation of Mechanical and Water Absorption Behaviours of Corn Shell/Pumice Reinforced Epoxy Composites
}

\author{
Menderes Koyuncu ${ }^{1}$ \\ Department of Textile, Van Vocational Higher School, Van Yuzuncu Yil University, Van,Turkey ORCID:0000-0002-4900-9327, menderes@ yyu.edu.tr
}

(Uluslararası Araştırma-Geliştirme ve Tasarım Konferansı - 15-18 Aralık 2021)

(DOI: 10.31590/ejosat.1042310)

ATIF/REFERENCE: Koyuncu, M. (2021). Evaluation of Mechanical and Water Absorption Behaviours of Corn Shell/Pumice Reinforced Epoxy Composites. Avrupa Bilim ve Teknoloji Dergisi, (32), 573-576.

\begin{abstract}
The research article focused on the effect of corn shell reinforced with epoxy composites. The randomly oriented corn shell reinforced/epoxy composites were prepared by hand lay-up technique with $5 \%, 10 \%, 15 \%, 20 \%$, and $25 \%$ pomice powder weight. Tensile, flexural, and water absorption tests were used to determine the composite's mechanical properties, The obtained results revealed that $20 \mathrm{wt} \%$ and $15 \mathrm{wt} \%$ pumice powdercould produce corn shell -reinforced composite with the highest tensile strength, flexural strength, and interfacial adhesion among all the prepared composites. The added of the pumice powder into the corn shell /epoxy composites enhanced their mechanical, and water absorption. The tensile and flexural strengths of the corn shell/pumice powde -epoxy composites (20wt\% and $15 \mathrm{wt} \%$ ) were 11.745 and $11.250 \mathrm{MPa}$, respectively. In additon, The $25 \mathrm{wt} . \%$, composite also displayed less water absorption behavior compared to the other composite.
\end{abstract}

Keywords: Natural fibers, Pumice, Mechanical properties, Composite, Water resistance.

\footnotetext{
${ }^{1}$ Corresponding author. Tel.: +904322251414 


\section{Introduction}

Nowadays, emphasis on the use of eco-friendly materials in various engineering applications has been continuously made by various nonprofit international organizations to curb the increasing carbon emissions and to protect the environment. Natural fibers are extensively used in aviation, automobile, and construction industries mainly due to the inherent advantages they provide like abundant availability, high specific strength, and stiffness, ease biodegradability, less health hazards while handling and low energy requirement for processing [1,2].In spite of its attractive advantages, natural fibers suffer from drawbacks like poor moisture resistance and poor thermal stability which limits their extent of use. In additon, One of the great disadvantages of naturally reinforced composite materials is poor interface formation. This causes poor compatibility between components and thus reduces the properties of composites. This results in poor compatibility among the constituents andhence decreases the properties of the composites.[3] However, many physical and chemical treatments are adopted to overcome these limitations and make natural fibers more suitable for composite manufacturing [4].Natural fibers with high crystalline cellulose possess high strength and stability and those with high lignin content exhibit high rigidity [5]. Natural fibers can be obtained from various parts of the plant such as stem, leaf, fruits, petioles, roots, and seeds [6].Recently, many novel plant fibers possessing the desirable characteristics required for reinforcing the polymer matrices have been identified and reported [1]. Corn shell is one such species from the stem of which good quality fibers can be obtained. Corn, known as Zea Mays L. belongs to the wheat family corn is widely cultivated throughout the world. It originates from Mexico and central America. A leaf emerges from each node of the plant. The plant usually has 16-18 leaves, the midrib of the leaf may be white or brown. It is widely used for making mats, brooms and baskets [7].

In the polymer composites, different types of fillers are used for improving the thermal, tensile, flexural strength and impact as well as other properties. [8,9].As there are several natural pumice mines in all around the world and many researches are about the effect of pumice powder on the mechanical properties of the fiber-reinforced epoxy composite, in this research the effect of pumice powder on the tensile,and flexural strength and water uptake properties of corn shell reinforced.

\section{Materials and Method}

\subsection{Materials}

In this study, corn husk particles as reinforcement and pumice powder as additive were used. Firstly, the corn shells were heated to $100^{\circ} \mathrm{C}$ to remove moisture, then ground in a planetary ball mill at $400 \mathrm{rpm}$ for 2 hours. The resulting corn husks were sieved to obtain a particle size of $80 \mu \mathrm{m}$. Epoxy resin EFLR-0190A and EFLR-0190 B hardener were obtained from Polisan\& Co, Istanbul, Turkey.

\subsection{Fabrication of composites}

The corn shell /epoxy composites were manufactured by using the hand lay-up technique. A metal mold of dimensions of $250 \times 25 \times 3 \mathrm{~mm}$ is used for manufacturing the composites. The wax is used to easily remove the composite plate from the die mold. For the preparation of composite sheets, a certain amount of corn husk particles and a certain amount of epoxy resin were taken into a plastic container and mixed thoroughly to obtain a homogeneous mixture. This process was repeated for the five weight formulations used for this research. The corn shell-epoxy and the fillers were mixed in different proportions while maintaining a total weight of $100 \mathrm{~g}$. Five mixtures with pumice powder compositions of $5 \mathrm{wt} . \%, 10 \mathrm{wt} . \%, 15 \mathrm{wt} . \%, 20 \mathrm{wt} . \%$, and 25 wt. $\%$ were composites obtained. The corn shell were added in the right proportions to the epoxy matrix. Then the mixture was poured into the mold and placed homogeneously. This scheme was kept at room temperature $23 \pm 20 \mathrm{C}$ for 24 hours. after it, curing the composite sheet was removed from the mold.

\subsection{Tensile Strength Test}

The tensile strength tests were carried out at room temperature at a rate of $2 \mathrm{~mm} / \mathrm{min}$ in accordance according to ASTM standard D3039 (2017), using a universal testing machine (Instron 3369, Norwood, MA) with a $50 \mathrm{kN}$ load cell. The length, width, and thickness of the sample were $250 \mathrm{~mm} \mathrm{x}$ $25 \mathrm{~mm}$ x $3 \mathrm{~mm}$ respectively. In each case, five samples were tested and their arithmetic average was recorded. The samples were pulled until they failed at room temperature.

\subsection{Flexural Strength Test}

The flexural testing was carried out according to the ASTM standard D790 (2017). The crosshead velocity was $2 \mathrm{~mm} / \mathrm{min}$, and the span length was set to $160 \mathrm{~mm}$. five samples were tested for the average value was recorded. The samples were attracted out until they failed at room temperature.

\subsection{Water Absorption}

Rectangular specimens ( $5 \mathrm{~mm}$ x $5 \mathrm{~mm}$ x $3 \mathrm{~mm})$ were used for water uptake tests. The samples were put in distilled water at room temperature for 30 days. After 30days the samples were withdrawn from the water, wiped with cotton cloth and then weighed. The percentage of water uptake was calculated according to the following. equation (Chung et al. 2018)

$$
\mathrm{W}_{\text {water uptake }}=\frac{W t-W 0}{W 0} \times 100
$$

$$
\begin{aligned}
& \mathrm{W}_{\mathrm{t}} \text { is the sample's weight after immersin } \\
& \mathrm{W}_{0} \text { is the sample's initial weigth. }
\end{aligned}
$$




\section{Results and Discussion}

\subsection{The Tensile Strength}

The tensile strength results of the composite material are shown in figure 1 . The figure clearly shows that filler loading has a significant effect on the tensile strength of the composite. In reference to Figure 1. When the amount of pumice powder increases up to $20 \%$ by weight, the tensile strength increases, then decreases, due to the increase in the percent by weight of the resin in the mixture. It can be explained by the increase in the amount of corn husk and the weak interface adhesion between the epoxy resin. During tensile loading partially separated micro spaces are created that obstructs stress

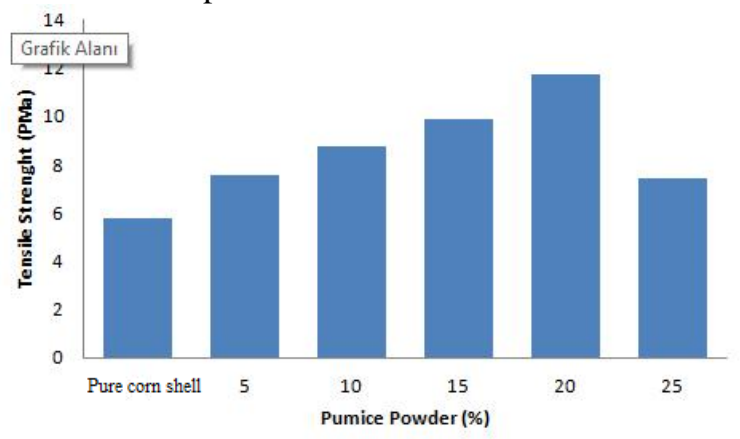

Fig. 1. Tensile property of composites.

\subsection{The Flexural Strength}

The experimental results show that the flexural strength increased up to $15 \mathrm{wt} \%$ pumice powder and then decreases (Figure 2) As illustrated in Figure 2, corn shell particles reinforced epoxy composite exhibited the highest flexural strength of $11.250 \mathrm{MPa}$ at $15 \mathrm{wt}$. \% pumice powder filler. It was found that when compared with $15 \mathrm{wt} \%$ pumice powder and pure corn shell composite the increasing degree is $9.92 \%$. The flexural strength of the corn shell reinforced/epoxy composite increased with increasing filler up to $15 \mathrm{wt}$. \% This probably causes an increased degree of crosslinking of the epoxy resin. A second possibility is attributed to the enhanced interfacial strength between the corn husk/pumice powder and the epoxy resin. [13]. After then, which a decrease was observed at 20 and $25 \mathrm{wt}$. \%. The reduction in the flexural strength can be attributed to controlled mobility of matrix by filler particles $[14,15]$

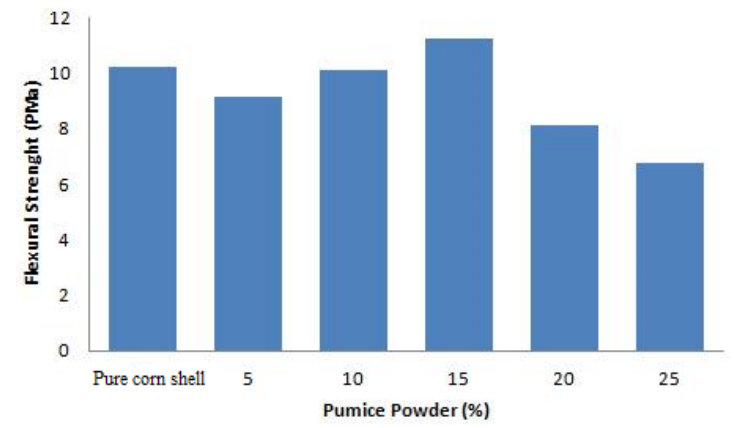

Fig.2. Flexural property of composites

propagation between the corn shell and the matrix The tensile strength of the composites material results are presented in figure 1. The results showed that the pumice added had a important effect on the tensile strength of the composite. During tensile loading, partially separated micro-voids are created between the corn husk and the epoxy resin that prevent the propagation of tension. The results of this study are in a similar trend with $[10,11,12]$.Palm Fiber/Peanut Shell Reinforced Epoxy Hybrid Composites; and Reddy and Reddy for gumbo fiber reinforced polymer composites, and effect of fillers loading on the mechanical properties of hardwood sawdust/oil bean shell reinforced epoxy hybrid composites.

\subsection{Water Absorption}

Figure 3 shows the water uptake curves for Pure corn shell and the corn shell/pumice powder blends. It shows that the water absorption percentages being $4.606 \%$ and 2.34 after 30 day for the pure corn shell and $25 \mathrm{wt} \%$ pumice powder panels respectively. The increase in water uptake decreased as pumice powder content increased from 5 to $25 \mathrm{wt}$. \% . the composites demonstrated fast water uptake on the first day, but the water uptake eventually reached an equilibrium state. Similar studies were observed by Chung, et al., and [13]. The water absorption rate of $25 \%$ by weight composite is lower than other composites. The general result can be interpreted as a result of water uptake of pumice powder or water uptake at the interface of corn shell/pumice [16,17].The maximum water uptake was measured for $4.606 \%$ corn shell composite. The increase in water absorption can be attributed to the hydrophilic nature of the corn shell. In addition corn shell have about $45 \%$ of their mass as cellulose. The cellulose molecule has a polar group. It forms water molecules through hydrogen bonding. Binding of water molecules to cellulose molecules leads to the accumulation of moisture in the cell walls. [18].

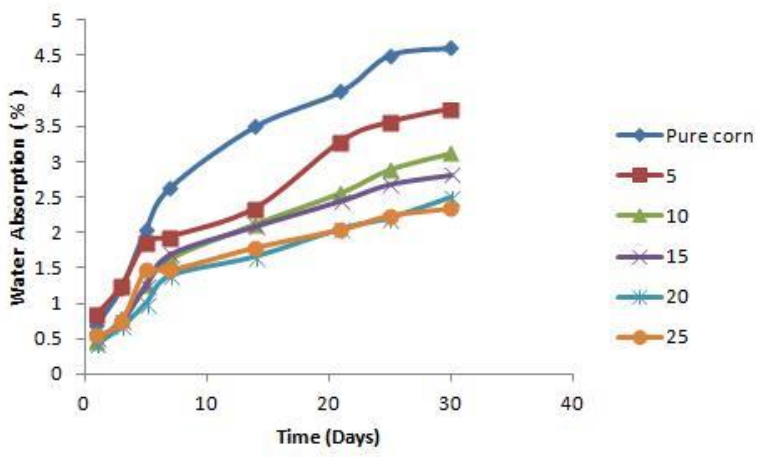

Fig.3. Water absorption curves of pure corn shell and corn shell/pumice powder 


\section{Conclusion}

The results of the study showed that pumice powder loading has an effect on the tensile and flexural strength properties of composites. It has been observed that the mechanical properties of composites are improved by adding $15-20 \%$ filler by weight. It has been observed that more weight gain decreases the tensile and bending values. The amount of water absorption decreased with the increase of pumice powder in composites.

\section{References}

[1] Gopinath, R., Billigraham, P., Sathishkumar, T.P., sanjay, M.R., Suchart, S. (2021). Characterization of Sida acuta fiber and its polymer composites with effect of fly ash. Journal of Natural fibers, 1-19.

[2] Vignesha, V., . Balajib, A.N., Karthikeyanc, M.V.(2017). Effect of wood sawdust filler on the mechanical properties of Indian mallow fiber yarn mat reinforced with polyester composites. International of polymer analyisi and characterization, 22(7), 610-621.

[3].Minelli, M., Angelıs, M.G.D., Doghıerı, F., Rocchetti, M.,Montenero, A. (2010). Effect of silica nanopowder on the properties of wood flour/ polymer composite. Polym. Eng. Sci., 50: 144.

[4] Soundhar, A., , J. (2021). Chemical and Morphological Analysis of Crab shell/Sisal Natural Fiber Hybrid Composites. Journal natural Fibers,18(10),1518-1531.

[5] Khana ,T., M. T. H. Sultan, Shah ,A. U. M., Ariffina , A. H., Jawaid, M. (2021).The Effects of Stacking Sequence on the Tensile and Flexural Properties of Kenaf/Jute Fibre Hybrid Composites. journal Natural Fibers, 18(3), 452-463.

[6] Venkatasudhahar, M., Ravichandran, A.T., Dilipraja, N. (2021). Effect of stacking sequence on mechanical and moisture absorption properties of abaca-kenaf-carbon fiber reinforced hybrid composite. Journal natural Fibers, 1-12.

[7]. Wikipeadia The free Encyclopedia, data of access : (7/11/2021).

[8] Koyuncu, M. (2018). The influence of pumice dust on tensile, stiffness properties and flame retardant of epoxy/ wood flour composites.Journal of Tropical Forest Science 30(1): 89-94 https://doi.org/10.26525/jtfs2018.30.1.8994

(2018)

[9] Rashiddadash, p., Rumezanianpour, A-A., Mahdikhani, M. (2014). Experimental investigation on flexural toughness of hybrid fiber reinforced concrete(HFRC) containning metakaolin and pumcie. Construction and Building material.51, 313-320..

[10] Nyior, G.B., Aye, S.A. and Tile, S.E. (2018). Study of Mechanical Properties of Raffia Palm Fibre/Groundnut Shell Reinforced Epoxy Hybrid Composites. Journal of Minerals and Materials Characterization and Engineering, 6, 179-192

[11] Chung T-J., Park J-W., Ji Lee H., Kwon H-J., Kim H-J., Lee Y-K., Tai Yin Tze W. (2018). The improvement of mechanical properties, thermal stability, and water absorption resistance of an ecofriendly PLA/Kenaf biocomposite using acetylation. Applied Sciences, (8): 376 doi/10.3390/aap.80330376

[12] Bolasodun, B., Durowaye, S., Rufai, I., Lawal, G. (2020). .Effects of Cure Temperature on the Mechanical Properties of Coconut Shell and Snail Shell Particles Reinforced Polyester Matrix Composites. Acta Materialia Turcica, 4,917

[13] Sun, T., Fan, H., Wang, Z., Liu, X., Wu, Z. (2015). Modified nano Fe2O3-epoxy composite with enhanced mechanical properties. Materials and design,87, 10-16.

[14] Prosper, O., Uguru, H. (2018). Effect of Fillers Loading on the Mechanical Properties of Hardwood Sawdust/Oil Bean Shell Reinforced Epoxy Hybrid Composite. Int J S Res Sci. Engg. Tech. 4(8), 620-62.

[15] Ismail, H., Edyhan, M. Wirjosentono, B. (2002). Bamboo Fiber Filled Natural Rubber Composites: The Effects of Filler Loading and Bonding Agent. Polymer Testing, 21, 139-144. https://doi.org/10.1016/S0142-9418(01)00060-5

[16] Masoodi, R., pillai, K-M. (2012). A study on moisture absorption and swelling in bio-based jute-epoxy composites. Journal refinforced Plastic\&composites, 3(5),285-294.

[17] Zahari,W. Z. W., Badril, R. N. R. L., Ardyananta,H., Kurniawan, D., Nor, F. M. (2015). Mechanical Properties and Water Absorption Behavior of Polypropylene / Ijuk Fiber Composite by Using Silane TreatmenProcedia Manufacturing. Procedia Manufacturing (2), 573 - 578

[18] Bher, A., Unalan, U., Auras, I., Rubino, R.M.,, Schvezov, C.E.(2018). Toughening of poly(lactic acid) and thermoplastic cassava starch reactive blends using graphene nanoplatelets. Polymers, 10(1),1-18. 